\title{
SURVIVAL AND GROWTH OF BIGTOOTH ASPEN ON ACIDIC SURFACE-MINE SOILS AS INFLUENCED BY PISOLITHUS TINCTORIUS AND NITROGEN AND PHOSPHORUS FERTILIZATION 1
}

\author{
G. DeMuro \\ E. M. Jencks \\ D. F. Hindal ${ }^{2}$
}

Abstract. $\quad$ Bigtooth aspen seedlings, Populus grandidentata, non-inoculated or inoculated with Pisolithus tinctorius (Pt) were transplanted to an acidic, infertile abandoned minesoil in May 1984. One year later 71 percent of the seedlings were surviving with no seedling losses between May and August of 1985. Nitrogen-fertilized Pt-inoculated seedlings had the lowest survival rate. The only significant growth increase occurred with treatment of $\mathrm{N}$ and $\mathrm{P}$ together for non-inoculated seedlings. Growth of aspen after 15 months showed no difference between uninoculated and Pt inoculation.

Additional key words: Aluminum, bulk density, iron, overburden, Populus grandidentata.

1 Paper presented at the 1990 Mining and Reclamation Conference and Exhibition, Charleston, West Virginia, April 23-26, 1990.

${ }^{2}$ G. DeMuro is Project Manager, Environmental Resources Management, Inc., 855 Springdale Drive, Exton, PA 19341, E. M. Jencks is Assoc. Professor and D. F. Hindal is Professor, Division of Plant and Soil Sciences, West Virginia University, Morgantown, WV 26506.

\section{Introduction}

Many areas surface mined for coal in Appalachia before the enactment of the Surface Mining Control and Reclamation Act of 1977 (PL95-77) have been abandoned and are now barren; hence, they are unsightly, desolate, and subject to severe erosion. Approximately 6100 hectares of such land are present just in West Virginia (B. Midcap, West Virginia Department of Natural Resources, 1984, personal communication).

Rather than revegetating abandoned minesoils with grass-legume mixtures which require periodic treatments with lime and fertilizer, a better alternative might be to return them to hardwood forests, a condition prevalent in Appalachia. Unfortunately, abandoned and 
unamended minesoils are acidic and low in nutrients, conditions that slow the establishment of most forest tree seedlings. Success in establishing native forest species, except black locust, (Robinia pseudoacacia, on minelands $\sim n$ Appalachia has been limited (Bramble 1952; Bramble and Ashley 1955; Schramm 1966; Marx 1980) without the application of lime and fertilizer at planting (Limstrom 1948; Austin and Strand 1960; Mays and Bengston 1978). Significant improvements in survival and growth of pine seedlings on disturbed soils have been obtained, however, when their roots were inoculated with symbiotic ectomycorrhizal fungi before transplanting (Marx and Artman 1979; Marx 1980). These symbionts, by extending hyphae into the soil, supplement nutrient absorption by plant feeder roots. Thus, mycorrhizal symbiont inoculation of hardwood seedlings prior to outplanting on low-fertility minesoils might reduce the need for lime and fertilizer. Little work has been reported on the use of mycorrhizal hardwood species for mineland reclamation (Schultz et al. 1981), although some success has been reported for red oak Quercus rubra) (Beckjord and McIntosh 1983; Beckjord and McIntosh 1984).

Species for forestation of abandoned minesoils should be selected from those present before mining or from those species, such as bigtooth aspen, a pioneer species that readily volunteers on minesoil. Numerous sites in northern West Virginia and western Pennsylvania where bigtooth aspen has naturally colonized abandoned minesoils have been observed by the authors and others (Bramble and Ashley 1955; Schramm 1966; Medve and Shan 1981). Up to 95 percent cover and good soil stabilization had occurred after within 25 years following replacement of the coal overburden. At these sites, climax species such as oak (Quercus sp.), hickory (Carya sp.), cherry (Prunus sp.), and yellow poplar (Liriodendron tulipifera) are becoming established. in addition to providing good ground cover, bigtooth aspen is also an excellent food source and cover for wildlife, and is valued by the wood and pulp industry.

Woody plant species volunteering on abandoned minesoils have been reported (Schramm 1966; Medve 1973; Marx 1980; Medve and Shan 1981) to require an ectomycorrhizal association for survival and growth. Iskra and Hindal (1985) found that Pisolithus tinctorus (Pt) was widely distributed on roots of volunteer bigtooth aspen on various minesoils in West Virginia. This fungus forms mycorrhizae on a number of tree species, including bigtooth aspen (Marx 1977), growing on coal minesoils or other drastically disturbed sites (Schramm 1966; Medve and Shan 1981). DeMuro (1986) showed that bigtooth aspen seedlings could be successfully inoculated with Pt and that this mycorrhizal fungus improved growth of greenhouse-grown bigtooth aspen seedlings on an acidic, infertile minesoil. "Starter" amounts of soluble $\mathrm{N}$ and $\mathrm{P}$ (as rock phosphate) enhanced the effect of this mycorrhizal fungus. The objectives of the present study were to determine if inoculating the roots of bigtooth aspen seedlings with Pt prior to transplanting would improve plant survival and growth on an abandoned, infertile minesoil, and to examine the effects of "starter" amounts of $\mathrm{N}$ and $\mathrm{P}$ on the development of Pt-inoculated and non-inoculated seedlings.

\section{Materials and Methods}

Seeds were collected from a volunteer bigtooth aspen stand in the vicinity of Morgantown, West Virginia. Five hundred plastic pots $(5.5 \mathrm{~cm} \times 8.0 \mathrm{~cm} \times 6.0 \mathrm{~cm})$ were sterilized with $10 \%$ chlorox solution, and then filled with steam-sterilized peat-vermiculite $(P V)(1: 1 \mathrm{v} / \mathrm{v})$ to a depth of $5 \mathrm{~cm}$. A $1 \mathrm{~cm}$ thick band of the fungus in PV (1:1 v/v) mixture (Isolate \#288, Sylvan Spawn Laboratories, Inc., Worthington, Pennsylvania) was placed on the surface of sterilized 
PV in 250 of the pots and covered with another $2 \mathrm{~cm}$ of sterilized PV. Sterilized PV was substituted for the Pt-PV inoculum in 250 pots in order to maintain uniform physical conditions. Ten seeds were placed in each pot. All plants were grown in the greenhouse under incandescent lights for a 16 hour photoperiod with the temperature being maintained at about $24^{0} \mathrm{C}$. The cultures were watered daily with distilled-deionized water. Two weeks after germination, seedlings were thinned to one per pot. Four, six, and eight weeks after germination, $\mathrm{NH}_{4} \mathrm{NO}_{3}, \mathrm{Na}_{2} \mathrm{HPO}_{4}$ and $\mathrm{KC} 1$ we e added in amounts to supply, $262 \mathrm{mg} \mathrm{kg}^{-1}$ of $\mathrm{N}$, $114 \mathrm{mg} \mathrm{kg}^{-1}$ of $\mathrm{P}$, and $243 \mathrm{mg} \mathrm{kg}^{-1}$ of $\mathrm{K}$. On May 10, 1984, eight weeks after germination, seedlings were placed outdoors for three weeks to harden. Plants were watered every third day, unless it rained.

On May 30, 1984, 112 mycorrhizal and 112 non-mycorrhizal seedlings, whose heights were within the standard deviation of the mean of each population, were transplanted to the minesoil. At the time of transplanting seedling roots were examined to confirm the presence or absence of Pt infection. There were few root mantles on plants in Pt-infested containers, but at least $30 \%$ of the roots had Pt hyphae growing along them (long wall infection). Seedlings in noninfested containers showed no evidence of infection.

The minesoil selected for this study was 26 years old, had not been topsoiled, and had never been limed ( $\mathrm{pH}$ 3.7), fertilized, or seeded. It was developing in Mahoning sandstone overburden replaced after surface mining of Upper Freeport coal in Preston County, West Virginia. Mahoning sandstone is typical of coal overburden in Appalachia. It is generally massive, but is often interspersed with thin-bedded shale and coal partings (Grube et al. 1971). The lower portion of the Mahoning is low chroma (gray) and often pyritic (up to $1.0 \%$ S), while the upper portion is highly weathered to a depth of about $6 \mathrm{~m}$ as evidenced by high chroma (red-brown), and is free of pyrite (Grube et al. 1972). Because no attempt was made to separate rock types when the overburden was replaced, it is a heterogeneous mixture of acid and non acid-forming sandstone and shale. Although minesoils developing in this material are generally loamy, they contain from 35 to 70 percent coarse fragments on a volume basis. Unless these minesoils receive fertilizer, they quickly become infertile because of acidic weathering and leaching. They also have relatively high bulk densities, and low porosities. The present miesoil had a bulk density of $1.48 \mathrm{Mg} \mathrm{m}^{-3}$.

The field experiment consisted of a factorial $(2 \times 2 \times 2)$ of eight treatments - Pt inoculated and non-inoculated seedlings with and without "starter" amounts of $\mathrm{N}$ and/or $\mathrm{P}$ in all combinations which were replicated four times. Plots, each $1 \mathrm{~m} \times 7 \mathrm{~m}$, were arranged in an eight $\mathrm{x}$ four plot layout and were separated by $1 \mathrm{~m}$ buffer strips. Seven bigtooth aspen seedlings, including the PV rootball, were planted in each plot at I $\mathrm{m}$ intervals. Because of the root bound-condition of seedlings at the time of transplanting, root balls were loosened which promotes root branching and growth (McLean 1976). Each seedling received $500 \mathrm{ml}$ of water at planting.

Two weeks before transplanting, "starter" amounts of $\mathrm{N}$ and $\mathrm{P}$ were broadcast on the plots selected for fertilization. Nitrogen, as ammonium nitrate, was added at the rate of $76 \mathrm{~kg} \mathrm{ha}$. Rock phosphate is moderately soluble in acidic media; thus it was expected to serve as a slow release form of $P$ in the acidic minesoil. Slow release of $P$ was desirable because it would prevent rapid fixation of applied $\mathrm{P}$ by the high levels of soluble Al and Fe in this minesoil (4.3 
$\mathrm{cmol}(+) \mathrm{kg}^{-1}$ of $\mathrm{KC} 1$-extractable $\mathrm{Al}$ and $90.2 \mathrm{mg} \mathrm{kg}$ - of DTPA-extractable Fe). To prevent deer browsing, a dome-shaped structure of $5 \mathrm{~cm}$ hex-mesh wire fencing was placed over each plot.

In August 1984, May 1985, and August 1985, one randomly selected seedling plus a $15 \mathrm{~cm}$ diameter and $15 \mathrm{~cm}$ deep portion of its root system was collected from each plot. The roots were separated from the stems and adhering soil was removed from the roots by gentle and repeated emersions in water. Tops were rinsed with distilled water. Both roots and tops were oven-dried at $680 \mathrm{C}$ for four days. Data on percentage survival and top and root dry weight were analyzed statistically using the Statistical Analytical System (SAS) and Duncan's New Multiple Range Test (Snedecor and Cochran 1967).

\section{Results and Discussion}

Transplanting was followed immediately by a hot, dry period. The US Weather Bureau Station at Brandonville, West Virginia (14 km from the study site), reported that rainfall for June 1984 was $3.63 \mathrm{~cm}$ below the normal of $5.97 \mathrm{~cm}$. Eight days after transplanting, 47 percent of the seedlings were severely defoliated. However, with the addition of $500 \mathrm{ml}$ of water per seedling on two occasions during the dry period and with above-normal rainfall $(+5.77 \mathrm{~cm})$ occurring during July and August of 1984, most of these seedlings produced new leaves. in August 1984, an average of 76 percent of the seedlings were still surviving (Table 1). Although at this date percentage survival did not appear to be related to treatment, the lowest rate of survival occurred in the Pt inoculated-N fertilizer treatment. This same difference was observed in May 1985. The reduction in survival associated with the $\mathrm{N}$-fertilized, Ptinoculated trees may have been caused by increased plant succulency induced by Ptenhanced $\mathrm{N}$ uptake. This may have caused seedlings to be more vulnerable to heat and moisture stress, diminishing their ability to survive. Beckjord (19V8) and Beckjord et al. (1984) found that greenhouse-grown, $\mathrm{N}$-fertilized, Pt-inoculated red oak seedlings suffered greater heat damage than seedlings receiving no $\mathrm{N}$.

Seventy-one percent of all seedlings still survived one year after transplanting, and no further losses occurred between May and August of 1985 (Table 1). Additional observations in September 1987 (not tabulated) indicated that 67 percent of the seedlings alive in August 1985 had survived and several trees were greater than $150 \mathrm{~cm}$ in height. This was a high rate of survival compared to results of other studies involving tree seedlings planted on abandoned minesoils (Medve 1973; Marx and Artman 1979). The high survival rate is of considerable interest since this site had a low pH, high Al and Fe contents, and high bulk density.

In May 1985, one year after transplanting, wide differences in growth as expressed as root and top weight were present among treatments (Table 2). However, few of the differences were significant. The minesoil studied varied considerably over short distances with regard to relative proportions of soil material and coarse fragments. Consequently, plant growth within treatments was quite variable which increased the differences required for significance. Since top dry weight in most cases was related to root dry weight, discussion will only consider the relationship between root growth and treatment.

Rather than improve root growth, inoculation with Pt appeared to have reduced root growth in August 1984 and in May 1985 when compared with the non-inoculated, unfertilized control. This apparent growth reduction seemed to have been counteracted by the application of both 
$\mathrm{N}$ and $\mathrm{P}$, which statistically increased seedling growth. Application of both $\mathrm{N}$ and $\mathrm{P}$ also increased the growth of non-Pt seedlings. It may be inferred that during the first year of growth, a mycorrhiza had not become well established and that the fungus competed with its host plant for nutrients, especially $\mathrm{N}$ and $\mathrm{P}$. Growth of Pt seedlings that had received $\mathrm{N}$ and $\mathrm{P}$ in combination was increased about the same degree as $P$ t seedlings receiving $N$ and $P$ individually. In contrast, growth of non-Pt seedlings that had been fertilized with $\mathrm{N}$ and $\mathrm{P}$ in combination was the greatest among treatments, in both August 1984 and in May 1985. These latter results would, again, suggest a competition for nutrients between the fungus and the host plant.

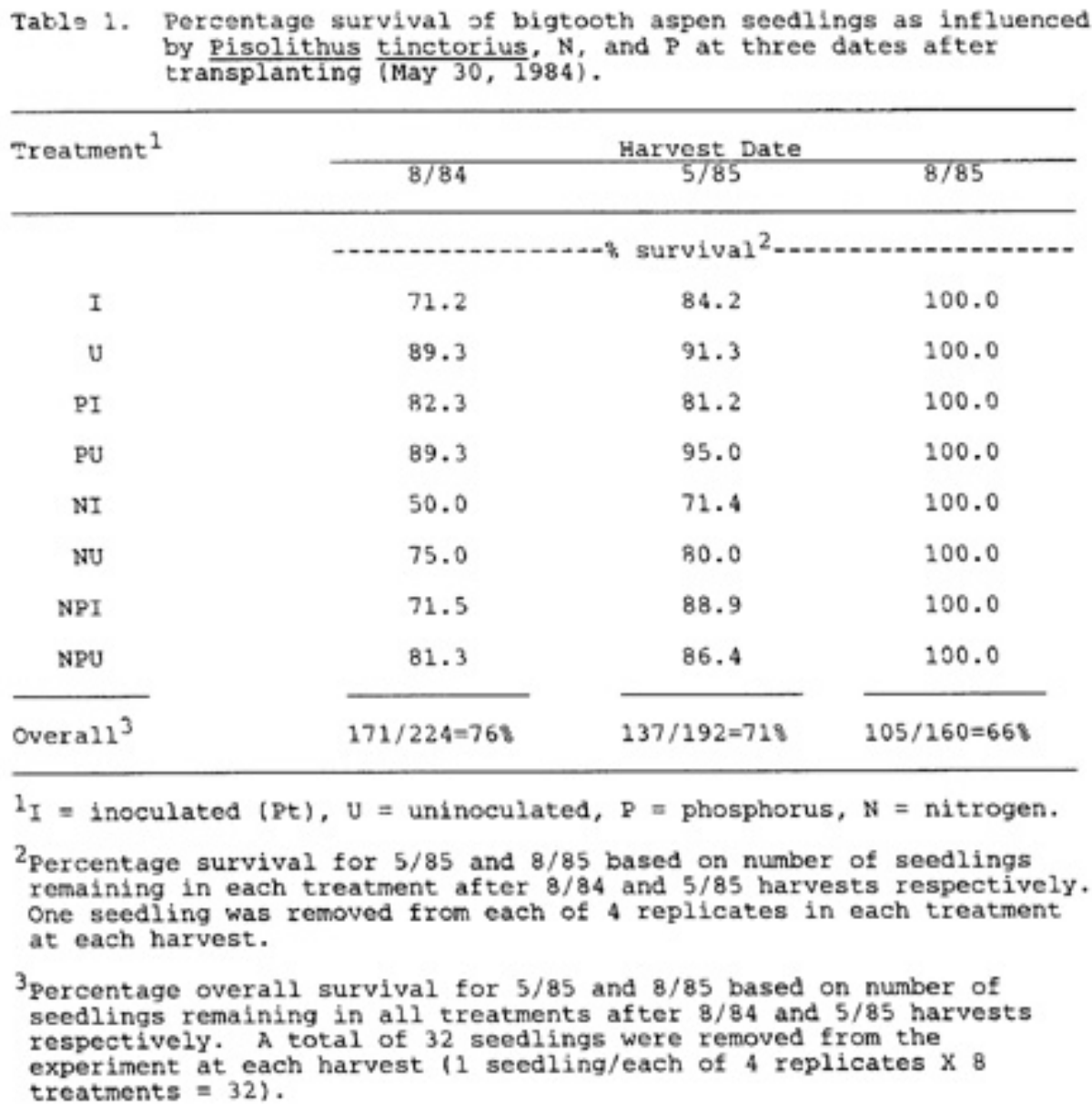

Based on the one-year growth data it may be concluded that inoculation with Pt is ineffective in promoting growth of bigtooth aspen on abandoned minesoils such as the one studied, and that "starter" amounts of both $\mathrm{N}$ and $\mathrm{P}$ are needed to enhance growth of uninoculated Ptbigtooth aspen. It also may be inferred from the one-year data that minesoil $\mathrm{N}$ and $\mathrm{P}$ were growth-limiting factors and that more emphasis should be placed upon these nutrients in forestation programs designed for old, acidic, abandoned minesoils, since most of them are commonly known to be low in $\mathrm{N}$ and $\mathrm{P}$. However, these conclusions may be modified after further growth.

In August 1985, 15 months after transplanting, root growth (and top growth) had increased several-fold in every treatment when compared to the May 1985 growth (Table 2). However, there were wide variations among treatments. The increases in root growth can be attributed to the normal climatic conditions that prevailed during the period beginning in the early 
and $\mathrm{P}$ levels by supplementing the roots in absorbing these nutrients from the minesoil. Data did not show any evidence in 15 months that inoculation of aspen with Pt was of any benefit over non-inoculated plants.

\section{$\underline{\text { References }}$}

Austin, R. C. and R. F. Strand. 1960. The use of slowly soluble fertilizers in forest planting in the Pacific Northwest. J. For. 58:619-627.

Beckjord, P. R. 1978. The incidence of ectomycorrhizae by Pisolithus tinctorius on Quercus rubra seedlings fertilized with sodium nitrate and ammonium chloride. Ph.D. Dissertation. Virginia Polytechnic Institute and State University, Blacksburg, Virginia.

Beckjord, P. R. and M. S. McIntosh. 1983. Growth and fungal retention by field planted Quercus rubra seedlings inoculated with several ectomycorrhizal fungi. Bull. Torry Bot. Club. 110(3):355-359.

Beckjord, P. R. and M. S. McIntosh. 1984. Growth and fungal persistence by Quercus rubra inoculated with ectomycorrhizal fungi and planted on a clear cutting and strip mine. Can. J. Bot. 62(8):1571-1574.

Beckjord, P. R., D. W. Smith, and M. S. McIntosh. 1994. Effects of nitrogen fertilizer and Pisolithus tinctorius on Quercus rubra seedling root and top development. For. Sci. 30:124128.

Bramble, W. C. 1952. Reforestation of strip-mined bituminous coal land in Pennsylvania. J. For. 50:308-314.

Bramble, W. C. and R. H. Ashley. 1955. Natural revegetation of spoil banks in Central Pennsylvania. Ecology 36:417-423.

DeMuro, G. 1986. The effect of Pisolithus tinctorius on the growth of bigtooth aspen on abandoned minesoil. M.S. Thesis, West Virginia University, Morgantown, West Virginia.

Grube, W. E., Jr., E. M. Jencks, R. N. Singh, R. M. Smith, and H. A. Wilson. 1971. Mine spoil potentials for water quality and controlled erosion. E.P.A. Proj. 10410 EJE. Environmental Protection Agency, Cincinnati, Ohio.

Grube, W. E., Jr., R. M. Smith, E. M. Jencks, and R. N. Singh. 1972. significance of weathering in a Pennsylvania sandstone to pollution from strip mines. Nature (London) 236-.70-71.

Iskra, A. and D. F. Hindal. 1985. Ectomycorrhizal associations of Populus grandidentata colonizing coal mine refuse. Phytopath. 75:625 (Abstract).

Limstrom, G. A. 1948. Extent, character, and forestation possibilities of land stripped for coal in the Central States. USDA Forest Service Tech. Paper. CS-109, USDA. Central States Forest Exp. Stn., Columbus, Ohio.

McLean, E. 0. 1976. Chemistry of soil aluminum. Comm. Soil Sci. Plant Anal. 7:619-636. 
Marx, G. D. 1977. Tree host range and world distribution of the ectomycorrhizal fungus Pisolithus tinctorius. Can. J. Microbiol. 23:217-223.

Marx, G. D. 1980. Role of mycorrhizae in forestation of surface mines. p. 109-116. In Proc. Trees for reclamation. Interstate Mining Compact Comm., USDA Forest Service. (Lexington, Kentucky, Oct. 27-29, 1980).

Marx, G. D. and J. D. Artman. 1979. Pisolithus tinctorius ectomycorrhizae improve survival and growth of pine seedlings on acid coal spoils in Kentucky and Virginia. Reclamation Rev. 2:23-31.

Mays, D. A. and G. W. Bengston. 1978. Lime and fertilizer use in land reclamation in humid regions. p. 308-328. In F. W. Schaller and P. Sutton (ed.). Reclamation of Drastically Disturbed Lands. Amer. Soc. Agronomy, Crop Sci. Soc. Am., Madison, Wisconsin.

Medve, R. J. 1973. Tree seedling survival on reclaimed bituminous strip mine spoils in Moraine State Park, Pennsylvania. Proc. Pa. Acad. Sci. 47:129-132.

Medve, R. J. and G. Shan. 1981. Distribution and plant associates of Pisolithus tinctorius on disturbed area in Western Pennsylvania. p. 72. In Abstracts of the Fifth North American Conference on Mycorrhizae.

Schramm, J. R. 1966. Plant colonization studies on wastes from the anthracite mining region in Pennsylvania. Trans. Amer. Philos. Soc. 56. 194 p.

Schultz, R. C., P. P. Kormanik, and W. C. Bryan. 1981. Effects of fertilization and vesicular arbuscular inoculation on growth of hardwood seedlings. Soil Sci. Soc. Am. J. 45:961-965.

Snedecor, G. W. and W. G. Cochran. 1967. Statistical Methods. lowa State Univ. Press. Ames, IA. 